\title{
Environmental Education: How Pre-service Teachers Are Incorporating Environmental Education into Their Practice
}

\author{
Sarah R. Edwards Moore \\ Susquehanna University, United States
}

\begin{abstract}
About the Author: Sarah R. Edwards Moore, Ph. D. is an Assistant Professor of Education at Susquehanna University. Her areas of research interest include English Language Learners, tutoring, student teaching practices, and classroom practices that support positive student outcomes.
\end{abstract}

\section{Abstract}

Currently, there are several initiatives and programs dedicated to educating students about issues related to the environment and sustainability. Very few studies if any have looked at how novice teachers are instituting environmental education into classrooms. This article looks at how preservice teachers engaged their students in environmental education activities after attending a workshop that gave them ideas on how to promote sustainability in their classroom. The pre-service teachers set goals on how they were going to teach students about the environment and then reflected towards the end of their student teaching experience on if they achieved those goals and how. Finding indicate that pre-service teachers did find minimal time to teach their students about the environment and that the methods they used were not tied to the goals that they set. Implications of this study will be useful to teacher education programs, teachers in the field, and student teachers. In the United States, environmental concerns and environmental education programs are becoming more prevalent and their aim is to connect youth to the outdoors and also prepare them for careers in conservation careers (US Department of the Interior, 2010) Therefore, it is not surprising that higher education institutions are creating centers for sustainability or focusing energy on the efforts that their current environmental centers are involved with. Apart from higher education systems, environmental education programs are being increasingly more commonplace in public school systems with the understanding that Environmental Education programs promote critical thinking, problem solving, and high academic engagement (Archie, 2003). With the understanding that environmental education is becoming more important in higher education and in K-12 public schools this study chose to look at how pre-service teachers were translating their sustainability learning, if at all, to students in their student teaching experiences. Several studies have looked at how students in K-12 spaces think about the environment after they are exposed to an education program or how the environment is connected to people's views of the world (Bruni \& Schultz,2010; Ernst \&Thiemer,2011; Wells \& Lekies,2011; Ewert, Place \& Sibthorp,2005; Cheng and Monroe;2010). Other studies have discussed how teachers need professional development in order to institute environmental education (Shepardson, Harbor, Cooper, \& McDonald, 2002; Fleming, 2009). Few studies, if any, have looked at the impact pre-service teachers are having in teaching environmental education concepts to their students. Considering the growing importance environmental education it was important to conduct a study that looked at how novice educators were incorporating environmental education into their classrooms.

Keywords: environmental education, student teachers, pre-service teachers

DOI: $10.7176 / \mathrm{JEP} / 10-33-01$

Publication date: November $30^{\text {th }} 2019$

\section{Background}

The preservice teachers were in the fall semester of their senior year and they were participating in their student teaching experience in the spring semester. The pre-service teachers were completing their certification at a small liberal arts college in central Pennsylvania where I serve on the faculty of the education department. The liberal arts college has over 60 acres of land devoted to conservation efforts and it houses an environmental center that includes a greenhouse, community garden, river research center, and solar panel energy space. The pre-service teachers will be working in Pre-K to $4^{\text {th }}$ grade classrooms and or special education classrooms during the spring semester.

\section{Method}

Ten student teachers were included in this study. The pre-service teachers participated in a workshop at the environmental center. This involved touring the center, learning environmental content, and ways that they could bring sustainability into their classrooms. After participating in the workshop, each preservice teacher filled out a reflection about the impact the workshop had and how they would plan to use what they learned at the center in their student teaching classrooms in the spring. Towards the end of the spring semester, the preservice teachers were asked to complete a second reflection were they discussed what they had done to teach their students about the environment. All of the reflections were coded for common themes and data related to 
the themes will be shown in discussed in the preceding sections of this paper.

\section{Data}

Below, each of the themes will be shown with samples of data that supports each theme from the reflections that the pre-service teachers completed. First, the student teachers initial goals will be shared after they attended the environmental workshop. The initial goals fell into three themes; Field experiences, Unit Plans, and Projects. Then the activities that they ended up doing will be shared from the data collected from their final reflections. The activities that they ended up doing were coded as One day layered activities, Environmental context used during regular scheduled events, and special events.

\section{Field Experiences}

Out of the 10 students sampled in this study, 5 set goals that wanted to take their students on field experiences. Below is the goals that each of the 5 set.

Student 1: I'd bring my students here. I would talk to them about how they can grow their own food and plants. I would also talk to them about energy from the solar panels.

Student 2: I would consider taking my class to the center and doing a tour of the facilities. I would also teach them about the solar panels.

Student 3: I could read them a book about the environment and then take them to the center.

Student 4: This would be a great place to take my students and it would go along with the topic of community

\section{Unit Plans}

Student 5: I learned the value of taking my class on field trips and it would be great to take them here.

Three of the students set goals that said they wanted to conduct prolonged units with their classes. The three student's goals are below.

Student 6: I would use the workshop at the environmental center to teach a variety of topics to my students. I would use it to teach students lessons about bees, gardens, solar panels, and greenhouses.

Student 7: I could plan a unit on environmental friendly resources

Student 8: I could use what I learned at the workshop to plan lessons that would expose my students to Projects gardening and introduce them to fruits and vegetables.

Two of the students sampled wanted to create environmental projects with their students. The two student's goals are below.

Student 9: I plan to grow some plants with my students that they can learn to care for

Student 10: I am a firm believer that kids should get down and dirty. Having my students create their own school garden would be ideal.

\section{Final Reflections}

Once the pre-service teachers wrote their final reflections on what they actually did in their classrooms to promote sustainability, the following themes emerged.

\section{One-day layered activities}

Five of the students ended up doing one-day layered activities. Their reflections are below.

Environmental content was used during regular activities.

Student 5: We spent time talking about the earth when we read the Lorax. As a follow up the kids wrote a note about what they would do to save the Earth and then they made their own tree inspired by the Lorax.

Student 9: We went through each step of a plant's life and made cute sunflowers. We also planted sunflowers in the soil and look at how they are growing each day.

Student 3: My students read a book about the earth, watched a video on how they can help, and then did a craft where they created their own Earth and thought of a pledge to help save the Earth.

Student 7: We played a no lose version of musical chairs where children had to sit on a seat with a matching image of how they can save the earth and during small group they got to paint with recycled materials.

Student 2: We made a hands on visual where students got to make an Earth after reading a book about the Earth. We then took the students on a nature walk where they got to check off things as they walked that they had learned about in the book.

\section{Environmental content during regular scheduled events}

Three students used environmental content during their regularly scheduled activities. Their reflections are below:

Student 1: I did a center for Math that was related to nature.

Student 6: I was able to squeeze in a math related activity where the students had to figure out the secret 
phrase and the phrase was reuse, reduce, and recycle.

\section{Special events}

Student 8: We did a writing piece during our writing time related to the Earth

Two of the students ended up planning special events. Their reflections are below:

Student 10: I planned a Family Event for Earth Day

Student 4: We made a special bulletin board for the school that represented us growing together which was especially for Earth Day.

\section{Findings}

Findings are that pre-service teachers only chose to teach environmental education during the designated Earth Day in April. No one chose to implement environmental education at any other time as a supplement or alongside their mandated curriculum. This finding suggest that without Earth Day, environmental curriculum might be lost in some education spaces.

The pre-service teachers did not follow through with the goals they set in the fall in regards to what they wanted to teach in regards to environmental education. Many followed the directions or activities supplied to them by their cooperating teachers instead of developing their own activities. This could be because student teaching tends to be a stressful time for pre-service teachers and they find that it is easier to follow plans rather than creating their own plans. The curriculum they taught tended to be more discussion based, video based, and reading based instead of hands on. Their activities tended to involve low prep and did not take an extended amount of time. Several pre-service teachers mentioned not having much time to teach about the environment which validates that is has not yet become a priority in the curriculum.

\section{Implications}

Environmental education needs to be implemented into the curriculum instead of during one week or day of the school year. Teachers need to find ways to implement environmental education in ways that don't cause them to take away time from the mandated curriculum. For instance, they could teach about the environment through the design of their rooms, the music they choose to play, and the content they use to teach standards. Even when pre-service teachers are exposed to environmental centers and sustainability efforts does not mean it will translate into an action based teaching curriculum into their classrooms. A more hands on monitored approach to supporting the pre-service teacher's goals they set in the fall many have increased their follow through. Future research could look at how entire schools or districts are supporting environmental education. Research could also look at what would happen if teachers were offered more explicit professional development on environmental education.

\section{References}

Archie, M. (2003). Advancing education through environmental literacy. Alexandria, VA: Association for Supervision and Curriculum Development.

Bruni, C.M., and P.W. Schultz. 2010. "Implicit beliefs about self and nature: Evidence from an IAT game." Journal of Environmental Psychology 30 (1): 95-102.

Cheng, J.C.-H., and M.C. Monroe. 2010. "Connection to Nature: Children's Affective Attitude Toward Nature." Environment and Behavior 44 (1): 31-49.

Ernst, J., and S. Theimer. 2011. "Evaluating the effects of environmental education programming on connectedness to nature." Environmental Education Research 17 (5): 577-98.

Ewert A, Place G, and Sibthorp J. 2005. Early-life outdoor experiences and an individual's 337 environmental attitudes. Leisure Sci 27: 225-239

Fleming,M.L.(2009).Environmental education professional development needs and priorities study. RetrievedApril16,2010fromhttp://cms.eetap.org/repository/modernnems_documents/EETAP_PD_Needs_an d_Priorities_Report.1.1.1.1.1.1.1.pdf

Shepardson, D.P. , Harbor, J., Cooper, B., \& McDonald, J. (2002). The impact of a professional Meg Riordan \& Emily J. Klein 137 development program on teachers' understandings about watersheds, water quality, and stream monitoring. The Journal of Environmental Education, 33(3), 34-40.

US Department of the Interior. 2010, February 8. Secretary Salazar unveils new and expanded 'youth in the great outdoors initiative.' http://www.doi.gov/news/pressreleases/ 20100208 release.cfm/index.cfm

Wells, N. M., and K. S. Lekies. 2006. "Nature and the life course: Pathways from childhood nature experiences to adult environmentalism." Children, Youth and Environments 16 (1): 1-24. 